\title{
TRADITIONS AND INNOVATIONS IN THE ACADEMIC DISCOURSE OF SCIENTIFIC RESEARCH IN THE XIX-XXI CENTURIES (ON THE EXAMPLE OF THE KREMENETS REGION)
}

\section{Skakalska I. B.}

\section{INTRODUCTION}

The acquisition by science of the features of academic discourse is accompanied by the appearance in its structure of innovative components. It is important to trace how the methodological and sociocultural principles of transformation of science into academic discourse with the synthesis of scientific-theoretical, scientific-production and scientific-educational activity took place over the centuries. Scientific research in the Kremenets region during the XIX-XXI centuries were held on the basis of educational institutions, therefore we emphasize the academic discourse, not just the scientific component. Because scientists did not only carry out research, but taught and popularized their own knowledge.

Kremenets region in the XIX century experienced educational, cultural and scientific rise, associated with the opening in 1805 of the Volyn gymnasium (since 1819 - the lyceum). Scientific research of that time replenished classrooms and the best students were involved in them under the guidance of teachers-scientists. A striking example is the scientific collaboration of V. Besser and A. Andrzejowski. In Kremenets in the XIX century formed a center of natural research. Volyn Lyceum not only gave young people a good foundation of natural knowledge, but also became a center of exact sciences (botany, mathematics, agronomy, mineralogy). It should be noted that some Kremenets teachers were members of the Warsaw Society of Science Admirers.

Early twentieth century characterized by the spread of local lore research in the Kremenets region, first of all, that is, the works of 
M. Teodorovich. It also had an explanation: there was no educational center around which scientists could gather and conduct their research on its basis.

Scientific discourse of the interwar period of the twentieth century concentrated around the restored Kremenets Lyceum and the scientific structures that were part of it (Volyn Scientific Institute, Museum of Kremenets Land named after Dr. Willibald Besser). Also some scientists from Volyn.

Modern academic discourses of scientific research are developing in scientific centers and laboratories, scientific problem student groups of the Kremenets Regional Humanitarian and Pedagogical Academy named after Taras Shevchenko. We observe the longevity of traditions in scientific research on local lore and natural sciences.

Considering this topic from a conceptual standpoint, it is necessary to outline the range of problematic issues. The first conceptual problem that determines the general structure of research is the need to study the scientific tradition in the context of modern change. After all, innovation must cover the whole spectrum of scientific research, and it should not be destructive, but complementary.

The second conceptual problem is that educational traditions continue in Kremenets, so there is an academic environment that creates a basis for scientific research. The main thing is that the achievements of scientific research are not hampered by various factors, in particular, financial.

The third conceptual problem is that research is pro-European. In the XIX century Volyn Lyceum focused on Vilnius University in its programs. Scientific research was conducted in line with the methodological traditions that prevailed in Europe, but not in the Russian Empire. The influence of European innovative technologies was felt in the interwar period of the twentieth century. In addition, some Volyn scientists worked in scientific and educational institutions in Warsaw, Krakow, Prague and others. The modern higher education institution cooperates with several European universities and supports European research projects. Topics of scientific discourses cover the problems of 
the humanities and natural sciences. The essence of the innovative component of modern academic discourse is studied, on the basis of which the ratio of its theoretical, pragmatic and socio-cultural aspects is analyzed.

Scientific-academic discourse, which unites communication in scientific and educational spheres, the purpose of which is to transfer the best achievements of scientific research and professional knowledge in the field of higher education of Kremenets region, which have a long historical tradition, is relevant despite innovations. Because there must be a basis for new research projects.

\section{Direction of scientific research in the XIX - early XX centuries}

The center of development and formation of scientific schools in the XIX century in Kremenets became the Volyn lyceum. The emphasis in the scientific work was on conducting basic research in the exact sciences. Thus, the researcher Wanda Grambetska aptly noted that "The research conducted by local botanists fit well into this area of science" . Among the leading scientists stands out the figure of W. Besser, the scientific direction of his research was floristics. His able student was A. Anzheiovsky. It is worth noting the fruitful cooperation of scientists, their joint expeditions to study the floristics of Volyn and Podillya. A. Andrzejowski officially became first an assistant and then an assistant (assistant professor) to his teacher W. Besser, they spend almost all their free time from high school students on trips supported by the Polish nobility. In addition, A. Anzheiovsky established cooperation with European scientists, Professor of Zoology at Vilnius University K. Eichwald and others ${ }^{2}$.

S. Zenovich's theory of metaphysical character was a well-known scientific concept of the philosophy of nature among scientists of that time. The scientist was thoroughly acquainted with the physics,

${ }^{1}$ Грембецька В. Ботаніка в Кременці: люди, навчання, дослідження. Волинські Афіни 1805-1833. Зб.наук.праць під ред. С. Маковського, В. Собчука. Тернопіль, 2006. C. 173-187.

${ }^{2}$ Там само. С. 182. 
chemistry and natural history of that time. He combined the learning process with scientific research. His scientific discourses provoked a lively discussion in the academic environment outside of Kremenets ${ }^{3}$.

The researcher also taught his theory during lectures at the Volyn Lyceum in Kremenets. This was a useful practice, both for the scientist and for his students, because the scientific findings of the research were combined with theory and discipline. Professors of Volyn Lyceum encouraged their students to scientific activity. It is clear that these were only skills of scientific work. Scientific centers of youth were created in the educational institution. Their purpose was to cultivate interest in scientific research and the realization of creative abilities of young people in various fields of science and culture. Suffice it to say that the famous philosophers and historians Jan Senkiewicz, Karl Senkiewicz, and Tit Shchelevsky emerged from these societies; Polish fiction writers Jan Sovinski, Gustav Olizar; famous writers Yu. Krashevsky, N. Dobrovolsky. Characteristic of these societies was the presence of democratic principles (election of the chairman of the society, discussion of scientific abstracts and public speeches with them, publishing the best works in scientific journals), combined with a certain conservatism (organizers and leaders were exclusively teachers, membership in the society was elitist, political and religious problems were avoided in the research topics, polemics were not allowed at the meetings and, in general, there were teachers-censors on the research topic) ${ }^{4}$. After the closure of the Volyn Lyceum, scientific research in Kremenets in the natural sciences ceased, and was conducted mainly to study the history and culture of the region.

Local lore research occupied an important place in the scientific research of scientists. Local historian M. Teodorovych belongs to the Volyn local historians of the end of the XIX - XX centuries, who

${ }^{3}$ Гарбовська Я. Стефан Зенович - кременецький теоретик природничих наук. Волинські Афіни 1805-1833. Зб.наук.праць під ред. С. Маковського, В. Собчука. Тернопіль, 2006. С. 187-194.

${ }^{4}$ Коляденко О. С. Кременецький ліцей у системі освіти Волині (XIX - 30-ті pp. XX ст.). Житомир, 2003. С. 143. URL: http://eprints.zu.edu.ua/4339/1/MONOGRAFIJA_ $\%$ D0\%904.pdf 
gathered in Kremenets around the Volyn Theological Seminary, the Volyn Historical and Statistical Committee and the periodical "Volyn Diocesan Information". In general, his research did not go beyond the official historiography of the time and was based mainly on the philosophy of positivism. However, the factual and source material collected by him did not lose its value, and the first, although Russianlanguage, five-volume fundamental encyclopedic work "Volyn. Historical and Statistical Description of Churches and Parishes of the Volyn Diocese "has no analogues in the region and today itself is a powerful historical and local lore source.M. Teodorovich used local static material in his research, as well as information obtained from local priests. His works of the early twentieth century. became the basis for further local lore research. In the field of his scientific interests was the history of Kremenets. Among M. Teodorovich's researches, it is necessary to specify "History of the city of Kremenets", "Volyn in descriptions of cities, towns and villages in church-historical, geographical, ethnographic, archeological, etc. relations". Interesting and important as a historical source for researchers is the book "Historical and statistical description of churches and parishes of the Volyn diocese", which was published in five volumes. The first three volumes of the work were recommended by the Academic Committee of the Ministry of Public Education for the purchase by libraries of educational institutions of Kyiv and Vilnius educational districts. In 1904, M. Teodorovich's work "History of the City of Kremenets" was published in Sidlets, in which the researcher offered his views on the history of the city of Kremenets, Volyn Province 5 .

During the Kremenets period of M. Teodorovych's life, a historical and statistical description of the Volyn eparchy was created. The leadership of the seminary invited $\mathrm{M}$. Teodorovich to compile a "Commemorative Book" of the parishes of the diocese. The young researcher, getting acquainted with the statistics of benefactors, the archives of the Volyn consistory, analyzing the Volyn pages in the works

\footnotetext{
${ }^{5}$ Теодорович М.І. Історія міста Кременця. Сідлець, 1904. 141 с.
} 
of V. Tatishchev, M. Karamzin, M. Maksimovich, a collection of documents "Archives of Southwest Russia", etc., admired the Volyn region and came up with a complete "Historical and statistical description of the Volyn diocese." He began his work by adding historical texts, documents, priestly testimonies, and other records to short clerical descriptions. Thus, first in the "Volyn Diocesan Gazette", and then in separate books, descriptions of 1477 parishes and churches of 10 Volyn counties appeared ${ }^{6}$.

It is necessary to analyze the research of the local historian to generalize and understand the scientific achievements of the period. M. Teodorovych begins the work "History of the city of Kremenets" with a description of the physical and geographical location of Kremenets. The author notes that the city center is located in a ditch surrounded by mountains. The researcher notes that from the flint, which is in large quantities in the vicinity and the city itself was named - Kremenets. Mykola Teodorovych teaches the history of the city in a popular science form. Of course, the report on the city begins with the history of the castle, noting that it was built in the ninth century. As proof, the author cites data from his description, compiled on July 21, 1545, which states that the castle has existed since time immemorial. The book also tells about the rulers of Kremenets Castle and the city - the Mokosi family ${ }^{7}$.

The author proudly notes that in 1240 Kremenets withstood the siege of the Mongols, led by Khan Batu. It was Kremenets that stood in the way of their conquests further west. M. Teodorovych traces the history of the city under the rule of the Grand Duchy of Lithuania. In the history of medieval Kremenets a prominent place belongs to Prince Svidrigail. At Kremenets in the late fifteenth and early sixteenth centuries. Crimean Tatars repeatedly attacked. The raids in 1497 and 1500 were especially devastating. We also find information about this in

6 Скакальська I. Питання краєзнавства за науковим доробком Миколи Теодоровича «Історія міста Кременця». Збірник наукових праць. Серія «Історія та географія» / Харк.нац.пед.ун-т ім. Г.С. Сковороди. Харків: Планета-Прінт, 2009. Вип. 35. C. 158.

${ }^{7}$ Теодорович М.І. Історія міста Кременця. Сідлець, 1904. С. 11-14. 
the work of M. Teodorovich. The author reports that on April 4, 1536, King Sigismund I the Elder of Poland gave the city of Kremenets and the surrounding area to his wife Bonnie, with the obligation to strengthen the castle and maintain a military garrison. Kremenets belonged to Queen Bonnie for 20 years until she left for her homeland of Italy in 1556. Bona ruled the city through the elders: Stanislaw Falczewski and Felix Hercyk, who were engaged in the improvement of the castle. A significant array of material from M. Teodorovich's book is devoted to the descriptions of Queen Bonnie's castle. Describes the author and the destruction of the castle by the Cossacks under the leadership of Colonel Maxim Krivonos in 1648 during the national liberation war led by B. Khmelnytsky ${ }^{8}$.

The author writes about the construction of the Jesuit college in the city in 1731-1743 and characterizes its functioning. The history of the Volyn gymnasium (lyceum) founded by Tadeusz Chatski, traced by Mykola Teodorovych from the time of its foundation to its transfer to Kyiv. In particular, the gymnasium was opened on October 10, 1805. Education in the gymnasium lasted 10 years and was divided into seven classes, the first of which were two years. They included: geography, history, mathematics, architecture, botany, God's law, moral sciences, agriculture, horticulture, political economy, physics, chemistry, law, language and literature - Polish, Russian, French, German, Greek and Latin, as well as music, horseback riding and swimming ${ }^{9}$.

Thus, to study the history of education in Kremenets, the study of M. Teodorovich can provide maximum information. For example, in 1836 the Volyn Theological Seminary was transferred to the premises of the former lyceum. With the transfer of the seminary to Zhytomyr, the Volyn Diocesan Women's School was located in these buildings.

It should be noted that M. Teodorovych does not ignore the cult buildings of the city, even those that have not survived to this day. In particular, a description of the castle church of St. Mykhailo, which was located on the Castle Hill, near the left wall of the castle. It was built at

\footnotetext{
${ }^{8}$ Там само. С. 28-44.

${ }^{9}$ Там само. С. 55- 62; 95.
} 
the beginning of XII century by the head of the castle Gavril Denis Mokosiy in memory of his brother Mikhail. The church is mentioned in the lustration of Kremenets Castle from 1552. This position of the author in the work "History of the city of Kremenets" corresponds to the circumstances of the time when the study was written, it became the basis of many local lore. Collected M. Teodorovych factual and source material has not lost its value and is a powerful historical and local lore source. His works since Ukraine's independence are the most popular in writing research on the history of the Volyn region. Undoubtedly, M. Teodorovych's research "History of the city of Kremenets" and his other works had a significant impact on the formation of public opinion and contributed to the education of patriotism in many fields. A number of other works of the Volyn researcher have not yet been studied in detail by scientists.

Thus, the academic discourse was formed around the Volyn Lyceum, and later the Volyn Theological Seminary.

\section{Scientific discourse of the interwar period of the twentieth century}

An important center of academic scientific discourse in the interwar period of the twentieth century Kremenets Lyceum was restored. The Volyn Scientific Institute operated at the Kremenets Lyceum. His task was to coordinate scientific research in Volyn, to process the already collected material. Among the main areas of work was the organization of local lore research, publication of scientific papers and conferences ${ }^{10}$. It is clear that Polish scientists united around the Volyn Scientific Institute, but Ukrainian figures are also involved in its work.

An important center of scientific research in the interwar period of the twentieth century becomes the Museum of the Kremenets Land named after Dr. Willibald Besser. The museum was founded in 1937 as part of the Kremenets Lyceum. It was in one of the buildings of the school. It should be noted that from the first months of its work, the

${ }^{10}$ Держархів Рівенської обл., ф. 160. Гофман Якуб (історик, краєзнавець, депутат польського Сейму. Автор «Путівника по Волині»). оп. 1, спр. 76. Проект устава Волинського наукового інституту при Кременецькому ліцеї (1938 р.), арк.1. 
museum has established cooperation with other scientific institutions in Poland.There was also a constant correspondence of its employees with colleagues from other museums, such as Lviv, Warsaw, Krakow, with the Ukrainian National Museum "Hutsulshchyna". Josaphat Kobrynsky in Kolomyia, the Natural History Museum in Grodno, the Archaeological Museum in Warsaw, with the latter an exchange of archaeological exhibits. Among the staff of the museum is O. Tsynkalowski, as a delegate of the Archaeological Museum in Warsaw, he participated in the excavations initiated by the museum. I. Gipsky was also involved in the ethnographic work of the museum.

During this period, local lore research developed. It is important to mention the local lore work of M. Tuchemsky, a church and public figure, a graduate of the Volyn Theological Seminary. Accompanying Archbishop Alexei M. Tuchemsky, visiting Volyn parishes, he describes them in detail. The most famous work of M. Tuchemsky is "On the nooks and crannies of Volyn Polissya", it describes the journey of the Archbishop of Volyn and Kremenets in Volyn. For example, the author gives a geographical description of the area, notes what the population does, in particular, the parishioners of Nova Vyzhva have long been engaged in furriery ${ }^{11}$. The author illustrates his posts. The most valuable in these explorations is historical information about the region. Accordingly, the work of the researcher M. Tuchemsky aroused considerable interest among the people of Volyn about the historical and architectural monuments of Volyn, ancient temples, monasteries and fortresses.

In the field of archeology, Yu. Shumovsky, a priest, public figure, archaeologist, and ethnographer, made his discoveries. In 1938 he graduated from the Faculty of Archeology of the University of Warsaw. In 1934-1938 he was a delegate from Volyn to the Warsaw Archaeological Museum. Yu. Shumovsky is also known as an archaeologist, so we will dwell on his scientific achievements in this field of research. As the author himself writes, he was "terribly in love with

${ }^{11}$ Тучемський М. По глухих закутках Волинського Полісся. Церква і нарід. ч. 1-2. 1938. C. $42-49$. 
archeology." After receiving the certificate of a delegate from Volyn of the Warsaw Archaeological Museum, he began to officially conduct excavations, and at the same time graduated from the Faculty of Archeology of the University of Warsaw. Near his native village of Myrogoshchi, Yu. Shumovsky found many Neolithic tools and ceramics that belonged to the Trypillia culture. These were his first achievements, which interested all the museums of Poland and the Ukrainian National Museum in Lviv, where Mr. Sventsytsky and Mr. Pasternak worked ${ }^{12}$. In 1934-35 - a new discovery of a young scientist. He discovered wellpreserved Neolithic burials, which caused a sensation in Polish archeology. There was one burial of two skeletons of a man and a woman. There were many utensils in the grave with an ornament of cord pottery culture. All Polish newspapers wrote about this discovery ${ }^{13}$. Professors, archaeologists from Vilna, Krakow, Lviv, Poznan and

Warsaw came to Myrogoshcha to see the discovery. I. Feshchenko-Chopivsky, a Ukrainian metallurgist, statesman and public figure, was a representative of the technical sciences. He was born in Zhytomyr region. From 1920 - in Poland, for a long time he lived on the farm Yurkove near the village Vyshnivets in Kremenets district in Volyn, where in 1935 he bought an estate. The scientist was looking for gifted Ukrainian children in the Kremenets region and paid for their education at the Jagiellonian University. Since 1922, I. Feshchenko-Chopivsky has been a senior assistant at the Department of Metallurgy and Metallurgy of the Warsaw Polytechnic ${ }^{14}$. In the same year, at the invitation of the rector of the Mining and Metallurgical Academy in Krakow, he founded the Department of Metallography and General Metallurgy and held the position of head and professor of the department. In 1927 he defended his dissertation for the degree of Doctor of Sciences; in 1931 - a dissertation for the degree of habilitated doctor of sciences. From 1928 he was a

${ }^{12}$ Шумовський Ю. Зруйноване гніздо, чи Історія однієї священицької родини на Волині. Рукопис. Том 2. США, Саванна, 1994. С. 41.

${ }_{13}^{13}$ Tereny archeologiczne w pow. Dubieńskim. Dzien dobry. 1935.

14 Фещенко-Чопівський I. Хроніка мого життя. Життєписно-бібліографічний нарис. Визначні діячі НТШ. Львів, 2000. С. 73-211. 
scientific adviser, head of the research laboratory of the metallurgical plant "Bayldon" in Katowice. From 1933 he was a corresponding member of the Polish Academy of Technical Sciences. He was a full member of the Scientific Societynamed after Shevchenko, Societies of metallurgists and mechanics of Poland, Metallurgists of Germany. He has published more than 135 scientific papers in Ukrainian and foreign languages. In 1945, he was captured by Soviet special services in Katowice (Poland), brought to Kyiv, and illegally sentenced to 15 years in prison. He died in the Abez concentration camp (Komi Republic) ${ }^{15}$.

On the initiative of I. Feshchenko-Chopivsky, a scholarship fund named after Simon Petliura, who acted on the principles of public loan. The scientist understood that young scientists should be financially supported so that they could discover themselves and achieve results in scientific research. Dr. I. Feshchenko-Chopivsky repeatedly came to Western Volhynia with lectures. For example, on April 14, 1938, in Kremenets, in the class of the Kremenets Lyceum, a public lecture was given by Professor of the Krakow Mining Academy, Doctor of Engineering I. Feshchenko-Chopivsky on the topic: "What are the ways of modern craft?" The report, which brought together the Ukrainian intelligentsia of the city, was heard with deep interest ${ }^{16}$.

The scientific works of Ivan Vlasovsky, secretary of the Volyn Consistory, editor of the magazine "Church and People" in Kremenets are of interest ${ }^{17}$. He was an active public figure, theologian, scientist, professor. He is the author of a multi-volume work on the history of religion "An Essay on the History of the Ukrainian Orthodox Church." The author's opinion is correct that the Ukrainian people under the auspices and influence of the Orthodox Church created their national culture as a branch of general Christian culture ${ }^{18}$.

${ }^{15}$ Краєзнавчий довідник. Українська еліта Кременеччини міжвоєнного періоду XX ст. Автор-упорядник І. Скакальська. Кременець: ВЦ КОГПІ, 2012. 46 с.

${ }_{16}^{16}$ Відчит проф. І. Фещенка-Чопівського. Церква $і$ нарід. ч. 8-9. 1938. С. 373.

17 Чернихівський Г. І. Кременеччина від давнини до сучасності. Кременець : Папірус, 1999. 320 с.

${ }_{18}$ Власовський І. Нарис історії української православної церкви. Ремпринтне видання. т.4.ч.2. Київ, 1998. С. 5. 
From the educational point of view, I. Vlasovsky's article "New teaching methods and the science of religion in school" is practical. The author reveals the pedagogical systems of education of A. Kamensky, K. Ushinsky. Separately, I. Vlasovsky dwelled on the characteristics of the "Dalton Plan", called the advantages of this system of education. However, it also cites shortcomings, in particular, in the conditions of rural school life, to apply the Dalton system, and thus to adapt science to religion, is not an urgent issue ${ }^{19}$. Thus, the methods of teaching and educating the younger generation were also the subject of consideration of the Ukrainian intelligentsia.

The issues of theology, as well as the history of religion were the subject of research by Professor V. Bidnov. He worked for some time at the Theological Seminary in Kremenets. The number of scientific works of V. Bidnov is significant. In particular, archival materials (10 titles), works on the history of the church (23), articles on the history of Ukraine (15), monographs and biographical essays $(26)^{20}$ were published. As we can see, one of the activities of the spiritual elite was scientific work. In his article "Volyn in defense of the Orthodox Church in the sixteenth and seventeenth centuries." V. Bidnov talks about the spread of Protestantism in Poland and in Ukrainian lands. He emphasizes that the positive side of the victory of the Reformation was the creation of schools, the development of education. In this connection, the Jesuit Order intensified its activities. In order to prevent these influences on Ukrainians, the scientist suggests that one should create one's own educational institutions ${ }^{21}$. The author gives a description of education in the sixteenth and seventeenth centuries. The scholar's research interests include the history of religion, problems of education and biographical works.

Thus, the interwar period marked the development of science in the Kremenets Lyceum and its structural parts, as well as independent

${ }^{19}$ Власовський І. Нові методи навчання і наука релігії в школі. Церква $i$ нарід. ч. 6.1938 . С. $20-25$.

${ }^{20}$ Сакович Є. Ю. Спомини про професора В. О. Біднова. Церква $і$ нарід. ч. 7-8. 1936. C. 280.

${ }^{21}$ Біднов В. Волинь в обороні Православної церкви в XVI-XVII ст. За соборність. Луцьк, 1932. № 1. С. 12-18. 
research by humanities and partly technical sciences and theology, as in Kremenets at that time there was a seminary. It was a center of religious scientific intelligence.

\section{Trends in scientific research in modern Kremenets University}

Kremenets Regional Humanitarian and Pedagogical Academy named after Taras Shevchenko has a long educational and scientific traditions, whose scientists seek to develop and modernize them. The latest research centers, research projects, research laboratories focus their activities on solving current problems of education and science, respectively, create an academic discourse of scientific research.

The academy has international research centers ("Higher Education of Ukraine in the context of European integration", scientific moderator - Professor O. Beznosyuk, "Ukrainian-Polish historical border", scientific coordinator - Professor G. Stronsky), which are a continuation of the historical traditions of European scientific vectors cooperation of scientists of Volyn Lyceum with representatives of European universities.

In line with the research of the interwar period, local lore explorations of both the history of Kremenets in general and individual periods continue ${ }^{22}$. Since 2019 , the Academy has established the Center for Local Lore and Tourism, scientific moderator - Head of the Department of History and Teaching Methods Skakalska I. The realization of the idea of creating the Center became a reality during the international project "Innovative University and Leadership" (Poland).The purpose of the center is to involve young people in the study of the history of the region and the promotion of tourism in the Kremenets district. Among the main tasks are the following: 1). Popularization of knowledge on the history of Kremenets region and educational traditions of the Academy. 2). Providing methodological assistance to secondary schools to study the problems of local lore.

${ }^{22}$ Скакальська І. Б. Кременеччина у міжвоєнний період. Нескорена Кременеччина y першій половині XX cm. (сторінки пам'яті): Науково-документальне видання. За ред. В. Мазурка. Тернопіль, 2009. С. 15-73. 
3). Training of a group of creative guides and local historians. 4). Acquaintance of students and pupils with methods of collecting local lore material, performance of scientific researches. 5). Nurturing a sense of patriotism. The center outlined such practical ways to implement tasks as the preparation of scientific papers on local lore by teachers of the Department of History and Teaching Methods and students majoring in "History". Also reviewing and consulting scientific research of students of secondary schools of Kremenets district. Organization of thematic excursions, workshops, quests, round tables, book presentations, trainings on the history of Kremenets and Ternopil. Conducting scientific and methodological seminars and scientific readings for teachers of Kremenets district. Realization of practical knowledge by students during archeological and pedagogical practice. Visiting historical and cultural sites, museums of the region. Making presentations on the history of Kremenets and Volyn. An important scientific event was a scientific and methodological seminar on local lore and archeology 23 .

The academy under the leadership of leading scientists implements research projects: "Monitoring the state of the flora of Podillya and the physiology of higher plants", "Educational technologies for the formation of personal values in the system of continuing education" and others.

Research centers are a platform that unites well-known and young scientists. Among them are the following: "Theoretical and methodological principles of training future teachers for professional activities", "Problems of artistic and aesthetic education and upbringing of student youth in a national revival."

Fundamental research is carried out in scientific laboratories: "Laboratory of Ecological Monitoring and Experimental Biology", as part of its work carried out a project to study the composition of water reservoirs of Kremenets, also conducted floral expeditions, as once did V. Besser. The scientific activity of the laboratory "Physical and

23 Центр краєзнавства і туризму. Офіційний сайт Кременецької обласної гуманітарно-педагогічної академії ім. Тараса Шевченка. URL:

http://www.kogpi.edu.te.ua/index.php?option=com_content\&view=article\&id=1278:20 16-03-24-14-31-47\&catid=26:2011-11-14-09-37-14\&Itemid=273 
pedagogical factors of formation of a healthy way of life of youth" is important.

The research laboratory "Creativity of Ulas Samchuk and Borys Kharchuk: Art Chronicle of the 20th Century" has a literary-biographical and linguistic orientation. Kharchuk's readings are periodically held on the basis of the laboratory.

Research laboratories "Problems of man and philosophy of health", "Educational technologies in the system of continuing education" contribute to the establishment in academic discourse of the practice of using theory and applied achievements.

As part of the research laboratory "Modern trends in linguodidactics and discourse research" (scientific coordinator Associate Professor Semegin TS) published the second issue of the collection of student research papers "Verba magistri".

The academy trains young researchers. According to the results of the 2019 academic year, 13 graduate students (8 full-time and 5 parttime) study at the postgraduate course of the Academy in the specialty 011 Educational and Pedagogical Sciences. Four people are studying for a postgraduate degree at other higher education institutions. The international partnership cooperation of the academy with foreign institutions of Poland has been established, namely: Higher SocioEconomic School in Przeworsk (February 2019), Higher State Vocational School in Kholm (June 2019), Lublin Higher School in Rykach (November 2019), SAYHELLO SCHOOL Language School in Warsaw 40 (December 2019). The agreement on international cooperation with the University of Warmia and Mazury in Olsztyn (Poland) has been extended.

The teaching staff and students of the Academy were coorganizers and organizers of a number of scientific conferences. Among them: scientific conference "On the history of Poland and Ukraine" in the framework of the XV International Literary and Artistic Forum "Dialogue of Two Cultures - 2019" (September 8-9, 2019); XIX International Scientific Conference "Personality and Society: Confrontation or Consensus" in the framework of the International 
Methodological Symposium "Subject of Humanitarian Cognition" (September 9-13, 2019); All-Ukrainian scientific-practical conference "Cultural heritage of the Olympic movement in the system of humanitarian education of schoolchildren" (Rivne - Kremenets, November 12-13, 2019); V All-Ukrainian scientific-practical conference "Medical and biological problems of physical education of different groups, occupational therapy, inclusive and special education" (Lutsk, December 3, 2019); "Education in Kremenets: traditions and prospects" in the IV All-Ukrainian seminar-hiking trip "Kremenets sciense: open air, or Science in sneakers" (May 23, 2019); II All-Ukrainian scientificpractical Internet conference "Current state and prospects of education: theory, practice, innovation" (November 19, 2019); IV All-Ukrainian scientific-practical conference "Litteris et artibus: new horizons" (November 14, 2019); XV reporting scientific-practical conference of the teaching staff for 2018" (May 16, 2019) ${ }^{24}$.

An annual scientific seminar is organized at the academy, which is organized jointly with the specialists of the methodical office of the education department of the Kremenets District State Administration. During the seminar important problems of historical and local lore research, museum pedagogy, etc. are discussed ${ }^{25}$.

The following periodicals are published in the Kremenets Regional Humanitarian and Pedagogical Academy: Scientific Bulletin of the Kremenets Regional Humanitarian and Pedagogical Academy named after Taras Shevchenko. Series: Pedagogy. Issue 11; Kremenets comparative studios; Actual problems of humanitarian education. The Council of Young Scientists has published collections of scientific works: Literis et Artibus: new horizons; Kremenets sciense: open air, or Science in sneakers.

24 Звіт ректора за 2019 рік. URL : http://www.kogpi.edu.te.ua/images/stories/ /vchena_rada/zvit_rektora_2019.pdf

${ }^{25}$ В центрі уваги - музейна педагогіка. Офіційний сайт Кременецької обласної гуманітарно-педагогічної академії ім. Тараса Шевченка.

URL: http://www.kogpi.edu.te.ua/index.php?option=com_content\&view=article\&id=2 539:2019-11-29-17-48-45\&catid=71:2016-03-04-07-11-15\&Itemid=369 
Thus, traditions and innovations in the academic discourse of scientific research in the XIX-XXI centuries successfully continued, there is an academic environment that creates a basis for scientific research. It is important that historical and innovative models of science development in Kremenets region serve as a cultural basis, without which it is impossible to understand the ontological origins of the intellectual scientific community of the region as a whole and assess ways of science development in the future.

\section{CONCLUSIONS}

Based on a systematic approach that combines philosophical and methodological, historical, scientific, retrospective and sociocultural aspects, a study of the genesis of academic discourse, as well as its place and role in the information society, allows us to draw the following conclusions.

Around the educational centers of Kremenets and the XIXXXI centuries formed an academic discourse on research. A long historical tradition must be studied and best practices revived. Because, we understand from the words of K. Sagan that scientists are influenced by the cultural environment. Accordingly, scientists should continue their research and promote their knowledge ${ }^{26}$.

Research should be conducted on the methodological basis of best European and world practices. In the XIX century Volyn Lyceum focused on Vilnius University in its programs. Scientific research was conducted in line with the methodological traditions that prevailed in Europe, not in the Russian Empire. The influence of European innovative technologies was felt in the interwar period of the twentieth century. In addition, some Volyn scientists worked in scientific and educational institutions in Warsaw, Krakow, Prague and others. As an example, the modern academy cooperates with several European universities and supports European research projects.

${ }^{26}$ Саган К. Світ, повний демонів. Наука як свічка у пітьмі. Переклад 3 анг. М. Климчука. Харків, 2018. С. 235. 
In general, the scientific traditions of the nineteenth century have such positive aspects as innovation, European trends, study and promotion of local materials. In the twentieth century the activity of scientific institutions at the Kremenets Lyceum was effective.

It should be noted that science in Kremenets at the present stage is carried out on the basis of scientific tradition and rationality, formed in the process of a solid foundation of established traditions of research, through the prism of leading research centers of the past, research heritage of scientists from various fields. scientific knowledge who have successfully conducted their scientific research. In our opinion, the most acute problems for modern scientists, which are potentially threatening and need to be resolved as soon as possible, are the following: the outflow of personnel from science; unconvincing without mutual support innovative cooperation of science and business; insufficient funding.

\section{SUMMARY}

The author notes that the accelerated development of technology requires the creation and implementation of innovative forms of education. However, without the traditions formed in the process of a solid foundation laid in the XIX-XX centuries it is difficult to continue progress. The research analyzes and generalizes the methodology of research and scientific research of scientists in the historical context on the example of educational institutions in Kremenets. A comprehensive study of the history of science from the XIX to the XXI century. Based on a systematic approach that combines philosophical and methodological, historical, scientific, retrospective and sociocultural aspects, the genesis of academic discourse is studied and the following main trends are outlined: traditionality and inheritability of research methodology from teachers to students (Volyn gymnasium); regional implementation of scientific research, combining the study and research of the history of the region. 


\section{REFERENCES}

1. Грембецька В. Ботаніка в Кременці: люди, навчання, дослідження. Волинські Афіни 1805-1833. Зб. наук. праць під ред. С. Маковського, В. Собчука. Тернопіль, 2006. С. 173-187.

2. Гарбовська Я. Стефан Зенович - кременецький теоретик природничих наук. Волинські Афіни 1805-1833. Зб.наук.праць під ред. С. Маковського, В. Собчука. Тернопіль, 2006. С. 187-194.

3. Коляденко С. Кременецький ліцей у системі освіти Волині (XIX - 30-ті pp. XX ст.). Житомир, 2003. 136 c. URL: http://eprints.zu.edu.ua/4339/1/MONOGRAFIJA_\%D0\%904.pdf $141 \mathrm{c}$.

4. Теодорович М.I. Історія міста Кременця. Сідлець, 1904.

5. Скакальська I. Питання краєзнавства за науковим доробком Миколи Теодоровича «Історія міста Кременця». Збірник наукових праць. Серія «Історія та географія» / Харк.нац.пед.ун-т ім. Г.С. Сковороди. Харків: Планета-Прінт, 2009. Вип. 35. C. $157-159$.

6. Держархів Рівенської обл., ф. 160. Гофман Якуб (історик, краєзнавець, депутат польського Сейму. Автор «Путівника по Волині»). оп. 1, спр. 76. Проект устава Волинського наукового інституту при Кременецькому ліцеї (1938 р.), арк. 1.

7. Тучемський М. По глухих закутках Волинського Полісся. Церква і нарід. ч. 1-2. 1938. С. 42-49.

8. Шумовський Ю. Зруйноване гніздо, чи Історія однієї священицької родини на Волині. Рукопис. Том 2. США, Саванна, 1994. C. 41.

9. Tereny archeologiczne w pow. Dubieńskim. Dzien dobry. 1935.

10. Фещенко-Чопівський I. Хроніка мого життя. Життєписно-бібліографічний нарис. Визначні діячі НТШ. Львів, 2000. C. 73-211.

11. Краєзнавчий довідник. Українська еліта Кременеччини міжвоєнного періоду XX ст. Автор-упорядник I. Скакальська. Кременець: КОГПІ, 2012. 46 с.

12. Відчит проф. І. Фещенка-Чопівського. Церква $i$ нарід. ч. 8-9. 1938. С. 373.

13. Чернихівський Г. I. Кременеччина від давнини до сучасності. Кременець : Папірус, 1999. 320 с. 
14. Власовський I. Нарис історії української православної церкви. Ремпринтне видання. т. 4. ч. 2. Київ, 1998. 468 с.

15. Власовський I. Нові методи навчання і наука релігії в школі. Церква і нарід. ч. 6. 1938. С. 20-25.

16. Сакович Є. Ю. Спомини про професора В. О. Біднова. Церква і нарід. ч. 7-8. 1936. С. 280.

17. Біднов В. Волинь в обороні Православної церкви в XVIXVII ст. За соборність. Луцьк, 1932. № 1. С. 12-18.

18. Скакальська І. Б. Кременеччина у міжвоєнний період. Нескорена Кременеччина у першій половині XX cm. (сторінки пам'яті): Наук.-документальне видання. За ред. В. Мазурка. Тернопіль, 2009. С. 15-73.

19. Центр краєзнавства i туризм. Офіційний сайт Кременецької обласної гуманітарно-педагогічної академії ім. Тараса Шевченка. URL: http://www.kogpi.edu.te.ua/index.php?option=com_ content $\&$ view=article $\&$ id=1278:2016-03-24-14-31-47\& catid=26:201111-14-09-37-14\&Itemid=273

20. Звіт ректора за 2019 рік. URL : http:// www.kogpi.edu.te.ua/images/stories/vchena_rada/zvit_rektora_2019.pdf

21. В центрі уваги - музейна педагогіка. Офіційний сайт Кременецької обласної гуманітарно-педагогічної академії ім. Тараса Шевченка. URL: http://www.kogpi.edu.te.ua/index.php?option=com_ content\&view=article \&id=2539:2019-11-29-17-48-45\&catid=71:201603-04-07-11-15\&Itemid=369

22. Саган К. Світ, повний демонів. Наука як свічка у пітьмі. Переклад з анг. М. Климчука. Харків, 2018. 384 с.

\section{Information about the author: Skakalska I. B.,}

Doctor of Historical Sciences, Associate Pofessor, Head of the Department of History and Teaching Methods Taras Shevchenko Regional Humanitarian Pedagogical Academy of Kremenets 1, Litseina str., Kremenets, Ternopil region, 47003, Ukraine 